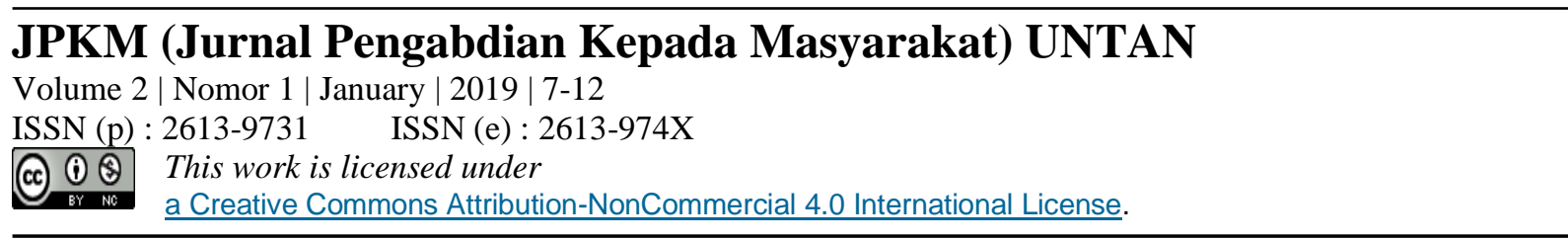

\title{
The Socialization of Class Action Research Implementation Based on Lesson Study
}

\author{
Siti Halidjah, Hery Kresnadi, Nuri Sidauruk \\ Universitas Tanjungpura, Pontianak, Indonesia \\ Email: sitihalidjah_pgsduntan@yahoo.co.id
}

\section{Keywords :}

Classroom Action Research,

Lesson Study

\begin{abstract}
The purpose of this PKM is to provide an understanding of the implementation of action-based classroom study research. The target audience in this activity is elementary school teachers in Pontianak City. There were 26 teachers involved and were representatives of several schools. The method of activities carried out in the form of socialization by presenting speakers who have competence in the field of classroom action research based on lesson study. From the results of community service activities with a focus on implementing action-based classroom study research, teacher's knowledge and understanding of the implementation of lesson study-based action research is getting better. In addition, the increasing interest of teachers to collaborate on lesson study in conducting research will be carried out because the stages contained in lesson study are simpler and help teachers be more thorough in carrying out classroom action research.
\end{abstract}

\section{INTRODUCTION}

Improving the quality of education can be achieved through a variety of ways, including improving the quality of educators and other education personnel, outreach, training and education, or by providing opportunities to solve learning and non-learning problems professionally through controlled action research.

The teacher is one of the human element in the education process. In the process of education in schools, teachers hold a dual-task that is as a teacher and educator. As a teacher, the teacher is tasked with pouring a number of learning material into the brains of students, while as an educator, the teacher is tasked with guiding and fostering students to become capable, active, creative, and independent human beings. Teaching and educating are the duties and responsibilities of the teacher as a professional. Therefore, the hard task of a teacher basically can only be carried out by teachers who have high professional competence that causes an increase in the quality and learning outcomes.

In carrying out their duties, ideally, the teacher is an agent of renewal. As an agent of regeneration, teachers are always expected to take innovative steps based on the results of evaluation and reflection on the learning they have done. Creative levels as a form of teacher paradigm change can be seen from the teacher's understanding and application of classroom action research based on lesson study. 
Lesson study is a model of fostering the profession of educators through a collaborative and continuous assessment based on the principles of collegiality and mutual learning to build learning communities. Lesson study is not a learning method or strategy, but lesson study activities can place various learning methods or strategy according to the situation, conditions, and problems faced by lecturers.

The use of lesson study as an activity in the steps of the research process is carried out starting from the perception equalization activities, planning, implementation, reflection, until the presentation of the results of the activities that have been carried out. With lesson study, lecturers can conduct learning in an orderly manner. The teacher prepares and presents the learning accompanied by a colleague. Indirectly, at the same time, the principal performs his function as a learning supervisor in the classroom.

Based on the description above, an effort is needed to provide a deep understanding of the implementation of classroom action research based on lesson study in the form of socialization, which leads to community service activities. Thus, community service activities are expected to be able to contribute ideas for increasing the mastery of elementary school teachers on the implementation of classroom action research based on lesson study.

Based on the background above, the problem in this PKM is how the teacher's understanding of the implementation of classroom action research based on lesson study is? In line with this, the purpose of implementing PKM is to provide an understanding of the implementation of classroom action research based on lesson study.

Action research, or better known as classroom action research, is a new paradigm in the world of education. This research was conducted to improve the quality of learning that has been done. Action research seeks to investigate a problem that demands real and immediate improvement. It is in line with the opinion of Sukmadinata (2005: 159) which states that action research is a study carried out by implementers in the work environment and Madya opinion (2009: 11), which states that action research deals directly with practice in the field in natural situations.

According to Ferrance (2000: 1), action research is a process in which participants examine their educational practices systematically and carefully, using the recharging of research (action research is a process of self-reflection systematically using research techniques). Action research is mostly related to the professional nature of lecturers, namely encouraging lecturers to become continuous learners in their classrooms and practices. Action research is a type of applied research that can be used to improve the quality of learning. This research is oriented toward solving problems in learning.

Based on some of the opinions above, it can be concluded that action research is applied research that can be used to improve the quality of learning, action research is oriented towards solving learning problems. Action research is an approach to improving education through changes by encouraging teachers to think about learning practices to be more creative and critical and to make changes towards better learning practices that have been carried out.

According to Abdulhak (2012: 94), the main characteristic of action research is research carried out through self-reflection. It means that in action research, practical practitioners, such as educators, are the main actors of research. Other characteristics are the background of practical problems in the implementation of the daily tasks of educators, held collaboratively between researchers, educators, principals or heads of organizers, students, and parents, and the dual role of educators as practitioners as well as researchers themselves. According to Emzir (2007: 25), action research aims to contribute to the practical care of people in problematic situations directly and to further the goals of social science simultaneously.

According to Darmadi (2011: 246), four essential steps in action research, namely the development of a plan (plan), act (action), observe (observation), and reflect (contemplation). The four steps can be described as follows.

Planning; A plan is a series of planned actions to enhance what has happened. In action research, the action plan must be forward-looking. Planning in action research should emphasize more on the strategic characteristics that can answer the challenges that arise in social change and recognize the real obstacles.

Action; The second step that needs to be considered is the carefully controlled action step. Actions in action research must be careful and planned for practical activities. It can happen if the action is assisted and refers to a rational and measurable plan. 
Observation; Observations on action research have the function of documenting the implications of the actions given to the subject. Therefore, observations must have several kinds of excellence, such as having a prospective orientation, having reflective basics of the present, and the future. Careful observation, in this case, is needed to overcome the limitations of the action taken by the researcher, which is caused by the restriction of breaking through existing obstacles in the field. As in planning, good observation is the observation that is flexible and open to be able to record symptoms that appear either expected or unexpected.

The fourth step is the reflective step. This step is a means to review the actions that have been taken on the subject of research and have been recorded in observation. This reflective step seeks to find a logical line of thought within the framework of processes, problems, issues, and obstacles that arise in the planning of strategic actions. This reflective step can also be used to answer variations in social situations and surrounding problems that occur as a consequence of planned action.

Lesson study is a collaborative teacher-based professional development originating from Japan (Hart, 2011: 1). To obtain maximum learning, teachers in Japan carry out planning and evaluation of learning in-depth with other teachers. Lesson study (jugyokenkyu) is a long-term form of activity, professional instructors, developed in Japan guide this activity, instructors systematically and collaboratively conduct research on teaching and learning in class to enrich the learning experience of students and improve the quality of their teaching.

Lesson study activities are useful to improve the professional abilities of teachers. Lesson study is important because the activity is beneficial to enhance the ability of teachers to master learning material, develop the skills of planning learning, improve the skills of applying methods and implementation of learning in general, improve the ability of teachers to make observations of students who are carrying out learning, improve the ability to cooperate with friends colleagues and by expanding the network, improving performance through the implementation of daily tasks and opening class isolation so that the increase in capability is obtained by not reducing the right of students to receive learning services.

According to Hendayana (2006: 39), the benefits of lesson study are (1) increasing lecturer knowledge about teaching materials and learning, (2) increasing lecturers' understanding of observing student learning activities, (3) strengthening collegiality relations between lecturers and with other observers besides lecturers, (4) strengthening the relationship between the implementation of daily learning with long-term learning goals, (5) increasing the motivation of lecturers to continually develop, and (6) improving the quality of learning plans including its components such as teaching materials and strategies learning ". The results of lesson study activities are expected to contribute significantly to improving the quality of education, in this case, improving the professional quality of lecturers. Thus the benefits of implementing lesson study can be used as a reference for improving the professionalism of lecturers.

Lesson study is a collaborative process carried out by a group of teachers in identifying learning problems, planning learning improvements, implementing learning with one of the teachers who taught it while other teachers as observers, evaluating and revising knowledge, implementing revised learning based on the results of the evaluation, evaluating again, and share (disseminate) the results to other teachers. Lesson studies are carried out in 3 (three) stages, namely plan (plan), do (carry out), and see (reflect) ongoing and never-ending (continuous improvement). The cycle of lesson study activities is shown in the following figure.
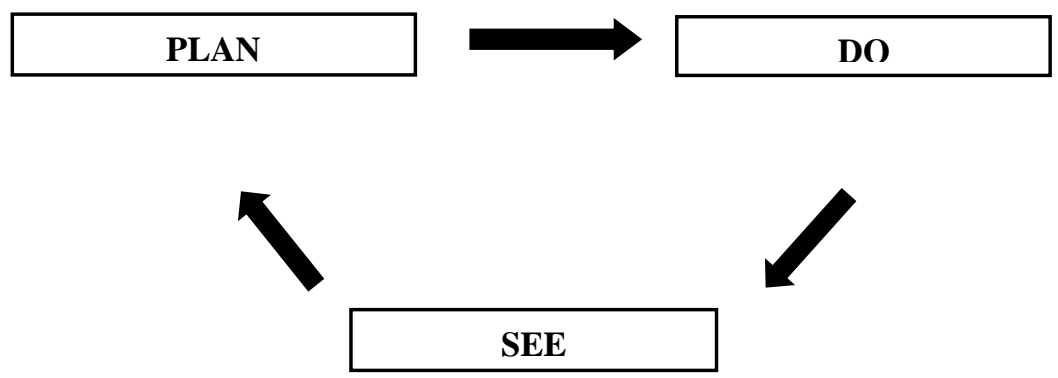

Fig. 1 Lesson Study Activity Cycle 
Reading the description above regarding the steps of classroom action research and lesson study, it can be seen that there are similarities between the steps of classroom action research. The following table shows more detailed steps of classroom action research and lesson study.

Table 1 Classroom Action Research and Lesson Study Steps

\begin{tabular}{|c|c|c|c|}
\hline CAR Stages & Activity & $\begin{array}{c}\text { Lesson Study } \\
\text { Stages }\end{array}$ & Activity \\
\hline Plan & $\begin{array}{l}\text { 1. Identify the } \\
\text { problem and its } \\
\text { cause. } \\
\text { 2. Make an action } \\
\text { hypothesis. } \\
\text { 3. Make an indicator } \\
\text { of the achievement } \\
\text { of actions. } \\
\text { 4. Creating lesson } \\
\text { plans / learning } \\
\text { scenarios. } \\
\text { 5. Making } \\
\text { Instruments } \\
\text { 6. Preparing media / } \\
\text { learning facilities } \\
\text { including teaching } \\
\text { material. }\end{array}$ & Plan & $\begin{array}{l}\text { 1. } \begin{array}{l}\text { Creating lesson } \\
\text { plans / learning }\end{array} \\
\text { scenarios. } \\
\text { 2. Prepare teaching } \\
\text { material. } \\
\text { 3. Prepare evaluation } \\
\text { tools or learning } \\
\text { assessments. }\end{array}$ \\
\hline $\begin{array}{l}\text { Action } \\
\text { Observe }\end{array}$ & $\begin{array}{l}\text { Carry out the actions } \\
\text { contained in the lesson } \\
\text { plan / learning scenario. } \\
\text { 1. Observing the } \\
\text { actions taken by } \\
\text { researchers. } \\
\text { 2. Using research } \\
\text { instruments to see } \\
\text { the achievements of } \\
\text { each action. }\end{array}$ & $\begin{array}{c}\text { Do (Action + } \\
\text { Observe) }\end{array}$ & $\begin{array}{l}\text { 1. Implement lesson } \\
\text { plans / learning } \\
\text { scenarios. } \\
\text { 2. Observe student } \\
\text { activities in using } \\
\text { teaching material } \\
\text { and receive from } \\
\text { the teacher's } \\
\text { actions during the } \\
\text { learning process. }\end{array}$ \\
\hline Reflect & $\begin{array}{l}\text { 1. Analyze the results } \\
\text { of observations } \\
\text { through feedback } \\
\text { discussions and } \\
\text { collected } \\
\text { instruments. } \\
\text { 2. Assess indicators of } \\
\text { achievement of } \\
\text { actions. } \\
\text { 3. Give feedback for } \\
\text { improvement and } \\
\text { improvement of the } \\
\text { next cycle. }\end{array}$ & See & $\begin{array}{l}\text { 1. Examine student } \\
\text { activities during } \\
\text { the teaching and } \\
\text { learning process } \\
\text { through feedback } \\
\text { discussions. } \\
\text { 2. Improve lesson } \\
\text { plans / learning } \\
\text { scenarios, teaching } \\
\text { materials, and } \\
\text { actions taken in the } \\
\text { next learning } \\
\text { process. }\end{array}$ \\
\hline
\end{tabular}

Based on Table 1, it can be seen that the core steps in classroom action research and lesson study are similar, namely, plan, action, observe and reflect. So it is natural if many teachers consider 
lesson study and action research in the same class. However, when we examine further activities at each step, it seems clear that lesson study activities are simpler than classroom action research. Even so, it does not mean both of them to run alone.

\section{METHOD}

This form of PKM is socialization about implementing classroom action research based on lesson study. Problem-solving is done with the framework, (1) determining the sources who have the ability in accordance with the theme of the activity to be carried out and (2) providing direct socialization activities.

The 26 participants were representatives of the teachers who were in Pontianak City. The form of activities chosen by the PKM PGSD FKIP Untan Team regarding the implementation of lesson study based on lesson study is socialization and counseling. Participants are given an explanation or general information about the implementation of action study classes based on lesson study, starting from the perception equalization stage to the presentation stage of the lesson study results.

The training was held on Saturday 1 October 2016 at 10:00 to 16:00 West Indonesia Time at Campus 2 PGSD FKIP Untan. The target audience in this activity is elementary school teachers in Pontianak City. There were 26 teachers involved and were representatives of several schools.

The PKM activities that are carried out are related to (1) class teachers or subject teachers, (2) Pontianak City National Education Office which is expected to support the implementation of programmed training activities, and (3) Tanjungpura University of Pontianak specifically FKIP Department of Basic Education Elementary School Teacher Education Study Program in implementing the Tri Darma of Higher Education, one of which is to carry out community service. The method of activities carried out is in the form of socialization by presenting competent speakers in the field of classroom action research based on lesson study.

\section{RESULTS AND DISCUSSIONS}

\section{A. Result}

The socialization of the implementation of classroom action research based on the lesson study was held on October 1, 2016. The activity began at 10:00 to 16:00 WIB at Campus 2 of PGSD FKIP Untan. The activity was attended by 26 participants consisting of teacher representatives in Pontianak City. The resource persons in the socialization activities were representatives from the PKM Teams of the FKSD Lecturer, FKIP Untan.

The teachers welcomed socialization activities. The number of teachers who attended was as planned. Participants in an orderly manner in attending the event and carefully listening to the explanation of the speakers. The results of the socialization activities are the teacher's understanding of designing and implementing action-based classroom study research for the better.

\section{B. Discussion}

Action research is research conducted by researchers as well as teachers, principals, school counselors, or other stakeholders in the teaching and learning environment. In action research, there are several kinds of implementation patterns developed. There are three action research models that can be used in carrying out action research. The three models are the Kemmis and McTaggart models, the Elliot model, and the McKernan model. Based on the three models, the Kemmis and McTaggart models are simple and easy to understand. This model uses the four most common stages in action research, namely planning, action, observation, and reflection.

Applications in the learning process using lesson study have in common with the stages used in the Kemmis and McTaggart Models, the planning stage of what will be done in the implementation phase. After lesson study planning, the implementation of learning in class, from the implementation as well as observing the learner. The observations are reflected in the next cycle as an improvement.

Lesson study is a vehicle for improving the quality of learning carried out by lecturers in collaboration, with the main steps of designing learning to achieve goals, implementing learning, observing the implementation of learning, as well as reflecting on discussing learning that has been carried out for material improvement in the next learning plan. Lesson study is a collaborative process 
carried out by a group of teachers in identifying learning problems, planning learning improvements, implementing learning with one of the teachers who taught it while other teachers as observers, evaluating and revising learning, implementing revised learning based on the results of the evaluation, evaluating again, and share (disseminate) the results to other teachers.

Lesson study becomes essential because the activity is beneficial to improve the ability of lecturers to master lecture material, improve skills in planning learning, improve skills in applying methods and implementation of learning in general, improve the ability of lecturers to observe students who are carrying out learning, improve the ability to cooperate with friends colleagues and by expanding the network, improving performance through the implementation of daily tasks and opening class isolation so that the increase in capability is obtained by not reducing the right of students to receive learning services.

\section{CONCLUSION AND SUGGESTION}

\section{A. Conclusion}

Based on socialization activities in the context of community service with a focus on the implementation of classroom action research studies based on lesson study, it can be concluded (1) the teacher's knowledge, and understanding of the implementation of lesson study-based actions is getting better and (2) increasing teacher interest in collaborating on lesson study in conducting research which will be done because the stages contained in the lesson study are more straightforward and help the teacher be more thorough in carrying out classroom action research.

\section{B. Suggestion}

Some suggestions that can be given considering the magnitude of the benefits of socialization activities in community service activities are (1) the need for similar activities in a sustainable manner given the existence of tertiary institutions, especially the PGSD FKIP Study Program Untan has essential benefits for community development around and (2) continuous cooperation between universities (LPTK) and the Ministry of Education is maximized to improve teacher professionalism through training, workshops, seminars, and so on.

\section{REFERENCES}

Abdulhak, Ishak dan Ugi Suprayogi. (2012). Penelitian Tindakan dalam Pendidikan Nonformal. Jakarta: RajaGrafindo Persada.

Darmadi, Hamid. (2011). Metode Penelitian Pendidikan. Bandung: Alfabeta.

Emzir. (2007). Metodologi Penelitian Pendidikan Kuantitatif dan Kualitatif. Jakarta: Rajawali Pers.

Ferrance, Eileen. (2000). Action Research. Northeast and Islands Regional Educational: Laboratory at Brown University.

Hart, Lynn C., Alice Alston, Aki Murata. (2011). Lesson Study Research and Practice in Mathematics Education. New Jersey: Springer.

Hendayana, Sumar., et al. (2006). Lesson Study: Suatu Strategi untuk Meningkatkan Keprofesionalan Pendidik. Bandung: UPI Press.

Madya, Suwarsih. (2009). Teori dan Paktik Penelitian Tindakan. Bandung: Alfabeta.

Sukmadinata, Nana Syaodih. (2005). Metode Penelitian Pendidikan. Bandung: PPS UPI dan Remaja Rosdakarya. 